\title{
MODELING AND STATISTICAL VARIATIONS OF LONG TERM OF MECHANICAL PROPERTIES OF CONCRETE MODIFIED WITH WASTE STEEL SLAG
}

\author{
Gona I. NOORI ${ }^{1}$, LinA A. F AQEMAHMOOD, SARKAN S. MOHAMMED andAHMED SALIH \\ College of Engineering, American University of Iraq Sulaimani-Kurdistan Region-Iraq
}

(Accepted for Publication: December 8, 2020)

\begin{abstract}
This study aims to evaluate and quantify the effect of steel slag (s), water-cement ratio (w/c), and curing time (t) together on the compressive and tensile strengths of concrete. In this research, the results were supported by more than $\mathbf{2 0 0}$ data collected from different research studies. The various watercement ratio used between $0.32-0.70$ with a different steel slag percent up to $100 \%$ as a complete replacement of fine aggregate (sand), and up to 90 days of curing time was considered. The strengths range of modified concrete up to $36 \%$ replacement of compressive and tensile strengths were between 10 70 MPa and 2-7 MPa respectively, and strengths of conventional concrete were between 10-62 MPa and 2$6 \mathrm{MPa}$ respectively. Concrete Mechanical properties with the use of steel slag, different range of w/c, and curing time were correlated using different numerical models which show that both predicted and experimented mechanical properties of conventional and modified concrete with steel slag are close to each other referring to the coefficient of determination $\left(R^{2}\right)$ and root mean square error (RMSE). Compressive $(\sigma c)$ and tensile $(\sigma t)$ strength of concrete as a function of w/c, curing time, and steel slag using the Non-Linear Model (NLM) resulted properly.
\end{abstract}

KEYWORDS: Water to Cement Ratio, Curing Time, Steel Slag, Mechanical Behavior, Modeling.

\section{INTRODUCTION}

C oncrete is a compound material which consists of cement, water, aggregates, and it is the most usable and old material for construction purpose. This wide use of concrete is because of its durability, low cost, and workability. The aggregates of concrete are consisting of fine and coarse aggregates by the percentage of $60 \%$ to $75 \%$ of the concrete volume and $70 \%$ to $85 \%$ by mass which have a major impact on the concrete's freshly mixed and hardened (Uddin et al., 2010). There are two principal classifications of concrete relaying on its compressive strength; high strength concrete (HSC) and normal strength concrete (NSC), as it is stated by (ACI Committee, 2011). HSC determined concrete as having a compressive strength of more than $55 \mathrm{MPa}$, and NSC determined concrete with a compressive strength which is slighter than $55 \mathrm{MPa}$ (Gupta et al, 2017 \& Burhan et al., 2019).

In the consistency of concrete's material, the water-cement ratio is a significant component of the concrete's mixture, the ratio of amount of the water to cement has a major effect on the behavior of concrete as its durability and strength. The typical range of using the watercement ratio (w/c) is between 0.4-0.6, and the proper percentage is being used depending on the changes in weathering. Regarding the effects of w/c on concrete strength, curing time also plays a significant role in such a manner. For having appropriate curing time, some factors that are needed to be taken into consideration as moisture curing duration and temperature of curing (Uddin et al. 2012 \& Tauqir, 2018).

Curing time can be effective by controlling the rate of hydration throughout the quality and amount of cementitious materials that exist in the mixture, optimum temperature and the amount of used moisture in the mixture (Uddin et al. 2012). Strength of concrete is another aspect and property of concrete that it should be taken into consideration, and the concrete with high range of strengths are the reliable and most usable type of concrete, as the resistance of pressure or durability and mechanical properties are much better than conventional concrete (Burhan et al, 2019 \& Akinwumi et al, 2014).

Having concrete with high strength requires appropriate water-cement ratio, temperature with curing time, and decrease in the percentage of porosity with micro-cracks, and the transition gi14142@auis.edu.krd, la14158@auis.edu.krd, ss14524@auis.edu.krd, Ahmed.salih@auis.edu.krd ${ }^{1}$ Corresponding author: College of Engineering, University of the American University of Iraq Sulaimani 
zone which is the region between the particles of coarse aggregate and the hydrated cement paste (Nemati, 2015). Enhancing the feature of concrete is unstoppable work and study for modifying weak and unwanted features, this development and modification can be gained by using different amount and size of fine and coarse aggregate, different types and amounts of wasted materials and additives either in liquid or powder state, various amounts of water-cement ratio, a various ingredient of concrete and newer techniques (Burhan et al, 2020). In this research, one of the types of wasted material or additive is studied for working on the modification of concrete features which is steel slag content. The additive is an additional material which is added to the concrete mixture within the cement and aggregates with the different amount for controlling the behavior and modifying the durability, workability and hardening of concrete (Burhan et al., 2019 \& Janković et al, 2011).

Steel slag content is a waste material that is produced from the process of making steel, and consists of chemical compounds of $\mathrm{SiO}_{2}, \mathrm{CaO}$, $\mathrm{Fe}_{2} \mathrm{O}_{3}, \mathrm{Al}_{2} \mathrm{O}_{3}$, and $\mathrm{MnO}$, with its main mineral components $\mathrm{C}_{3} \mathrm{~S}, \mathrm{C}_{2} \mathrm{~S}, \mathrm{C}_{4} \mathrm{AF}$, RO phase, and free-CaO (Liu et al, 2018 \& Anil et al, 2017). Steel slag content was used as mineral admixtures in the size of sand in different percentage for replacing sand in the mixture of concrete, for improving the strength of conventional concrete in different time of curing and different percentage of $w / c$, and data points have been collected from the various literate review, show the mechanical properties of concrete with and without steel slag content. The increase of concrete strength with the use of steel slag content was noticed, as the compressive strength of conventional concrete in 14 days of curing was $49 \mathrm{MPa}$, compressive strength of modified concrete with steel slag content replacing sand for 14 days of age with the same (w/c) was $61 \mathrm{MPa}$ (Palanisamy, 2015).

The effectiveness of water-cement ratio, curing time up to 90 days, and steel slag on mechanical properties of concrete showed through 7 model parameters (a, b, c, d, e, f, and g) (Burhan et al., 2019). The nonlinear square method (Least square method) was used to develop the equations. The model parameters were determined by adjusting the equation constants by setting the objective of optimization solver on the amount of square error between the experimental and expected data on the minimum value, and the model parameters are shown in
Table 4. Mechanical property models were conducted up to $36 \%$ of fine aggregate replacement by steel slag content. Then, proper relationships were drawn among both predicted and experimented compressive and tensile strength of conventional and modified concrete. Moreover, conventional and modified concrete properties were statistically analyzed and concluded in Table 3.

The overall aim of this research is to determine the compressive and tensile strength of modified concrete by steel slag content. In this research more than 200 data gathered from different literature, and the following are the specified aim of this research:

I. Using a statistical variation of steel slag content, curing time, water-cement ratio, the compressive and tensile strength of modified concrete by steel slag content.

II. Determining the compressive and tensile strength of conventional and modified concrete with steel slag content referring to the impacts of water-cement ratio, curing time, and steel slag through using the NLSM

II. The Vipulanandan model used to determine the compressive and tensile strength relationship of modified concrete with steel slag content.

\section{PROCEDURES AND MATERIALS \\ 2.1 Data collection}

The modification of the behavior of modified concrete with steel slag content is the main interest in this study. Concrete strengths are the mechanical properties of NSC and HSC. Tables $1 \& 2$ outline conventional and modified concrete characteristics.

\subsection{Modeling Expression}

\subsubsection{Vipulanandan Correlation Model for} tensile strength based on compressive strength

Using the Vipulanandan model, the physical properties of modified concrete by steel slag content can be found (Vipulanandan et al, 2020 \& Mohammed, 2018 \& Mahmood et al, 2020 \& Piraimathi, 2017). The following equation is recommended based on the collected data:

$$
\sigma \mathrm{t}=\frac{\sigma \mathrm{c}}{\mathrm{a}+\mathrm{b} \sigma \mathrm{c}}+\mathrm{c}
$$

This equation is to determine tensile strength based on compressive strength, where $\sigma \mathrm{t}$ represents tensile strength (dependent variable), and $\sigma c$ represents compressive strength (independent variable). ( $\mathrm{a}, \mathrm{b}$, and $\mathrm{c}=$ Model parameters). 


\subsubsection{Non-Liner Relationship Model for conventional concrete}

Non-Liner model was applied to obtain correlation mechanical strength of conventional concrete with water-cement ration and curing time (Burhan et al, 2019, 2020). This relations id defined as follow:

$\sigma=\mathrm{a}\left(\frac{\mathrm{w}}{\mathrm{c}}\right)^{\mathrm{b}} *(\mathrm{t})^{\mathrm{c}}$

Where $\sigma$ represents the mechanical property of conventional concrete (compressive and tensile strength) as dependent variables, and water-cement ratio (w/c) and curing time (t) is independent variables. $(\mathrm{a}, \mathrm{b}$, and $\mathrm{c}=$ Non- Liner parameters).

\subsubsection{Non-Liner Relationship Model for modified concrete with a steel slag content}

Non- Liner model is used to develop the relation between mechanical strengths of modified concrete with steel slag content and the three independent variables which are w/c, curing time, and steel slag content because those mechanical strengths do not depend only on w/c, curing time, or steel slag (Burhan et al, 2019, 2020). Following correlation defines Non- Liner model:

$$
\sigma=\mathrm{a}\left(\frac{\mathrm{w}}{\mathrm{c}}\right)^{\mathrm{b}} *(\mathrm{t})^{\mathrm{c}}+\mathrm{d}\left(\frac{\mathrm{w}}{\mathrm{c}}\right)^{\mathrm{e}} *(\mathrm{t})^{\mathrm{f}} *(\mathrm{~s})^{\mathrm{g}}
$$

Where $\sigma$ is the mechanical property of modified concrete as dependent variables (compressive and tensile strength), and watercement ration $(\mathrm{w} / \mathrm{c})$, curing time $(\mathrm{t})$, and steel slag content (s \%) are in-dependent variables. (a, $\mathrm{b}, \mathrm{c}, \mathrm{d}, \mathrm{e}, \mathrm{f}$, and $\mathrm{g}=$ Non - Liner parameters).

Table (1): Properties of conventional concrete collected from the literature

\begin{tabular}{|c|c|c|c|c|c|}
\hline Reference & w/c (\%) & $\begin{array}{l}\text { Curing time, } t \\
\text { (Day) }\end{array}$ & $\begin{array}{l}\text { Compressive } \\
\text { strength, } \sigma_{c} \\
(\mathrm{MPa})\end{array}$ & $\begin{array}{l}\text { Tensile } \\
\text { strength, } \sigma_{t} \\
(\mathrm{MPa})\end{array}$ & Types of test \\
\hline Gupta et al. (2017), [2] & - & $7-28$ & 23-39 & 3 & $\begin{array}{l}\text { Compressive and } \\
\text { Tensile Strengths }\end{array}$ \\
\hline Anil et al (2017), [7] & - & $7-28$ & $25-38$ & $2-4$ & $\begin{array}{l}\text { Compressive and } \\
\text { Tensile Strengths }\end{array}$ \\
\hline $\begin{array}{l}\text { Palanisamy et al. } \\
\text { (2015), [8] }\end{array}$ & 0.32 & $7-28$ & $40-62$ & $4-6$ & $\begin{array}{l}\text { Compressive and } \\
\text { Tensile Strengths }\end{array}$ \\
\hline $\begin{array}{l}\text { Shirale et al. (2009), } \\
\text { [12] }\end{array}$ & 0.55 & $7-28$ & $28-53$ & $2-3$ & $\begin{array}{l}\text { Compressive and } \\
\text { Tensile Strengths }\end{array}$ \\
\hline $\begin{array}{l}\text { Ulubeyli et al. (2015), } \\
\text { [13] }\end{array}$ & - & $7-28$ & $35-55$ & - & Compressive Strength \\
\hline $\begin{array}{l}\text { Olonade et al. (2015), } \\
\text { [14] }\end{array}$ & 0.62 & $7-28$ & $10-22$ & - & Compressive Strength \\
\hline Devi et al. (2014), [15] & 0.55 & 28 & 21 & - & Compressive Strength \\
\hline $\begin{array}{l}\text { ISMAILI et al. (2013), } \\
\text { [16] }\end{array}$ & 0.55 & 28 & - & 4 & Tensile Strength \\
\hline Khazaal (2014), [17] & $0.42-0.79$ & 28 & $15-35$ & - & Compressive Strength \\
\hline Abrol et al. (2016), [18] & 0.5 & $7-28$ & $17-25$ & 2 & $\begin{array}{l}\text { Compressive and } \\
\text { Tensile Strengths }\end{array}$ \\
\hline $\begin{array}{l}\text { Cabrera-Madrid et al. } \\
(2016),[19]\end{array}$ & $0.42-0.6$ & $28-90$ & $29-49$ & - & Compressive Strength \\
\hline Hilles et al. (2019), [20] & 0.37 & $7-28$ & $46-58$ & $3-4$ & $\begin{array}{l}\text { Compressive and } \\
\text { Tensile Strengths }\end{array}$ \\
\hline $\begin{array}{l}\text { Palson et al. (2017), } \\
\text { [21] }\end{array}$ & 0.45 & $7-90$ & $31-44$ & - & Compressive Strength \\
\hline $\begin{array}{l}\text { Ammash et al. (2017), } \\
\text { [22] }\end{array}$ & 0.68 & $7-28$ & $14-21$ & 2 & $\begin{array}{l}\text { Compressive and } \\
\text { Tensile Strengths }\end{array}$ \\
\hline Noori et al. (2018), [23] & 0.52 & $7-28$ & $25-39$ & - & Compressive Strength \\
\hline $\begin{array}{l}\text { Al-Ahdal et al. (2018), } \\
\text { [24] }\end{array}$ & 0.5 & $7-28$ & $28-30$ & $3-4$ & $\begin{array}{l}\text { Compressive and } \\
\text { Tensile Strengths }\end{array}$ \\
\hline $\begin{array}{l}\text { Munaf et al. (2001), } \\
\text { [25] }\end{array}$ & 0.28 & $7-90$ & $21-46$ & $2-5$ & $\begin{array}{l}\text { Compressive and } \\
\text { Tensile Strengths }\end{array}$ \\
\hline Ion et al. (2013), [26] & 0.4 & $7-28$ & $27-42$ & - & Compressive Strength \\
\hline
\end{tabular}

gi14142@auis.edu.krd, la14158@auis.edu.krd, ss14524@auis.edu.krd, Ahmed.salih@auis.edu.krd ${ }^{1}$ Corresponding author: College of Engineering, University of the American University of Iraq Sulaimani

(AUIS) 
Journal of University of Duhok, Vol. 23, No.2 (Pure and Eng. Sciences), Pp1-14, 2020 (Special Issue) $3^{\text {rd }}$ international conference on recent innovations in engineering (ICRIE) Duhok, September 9-10-2020

\begin{tabular}{|c|c|c|c|c|c|}
\hline $\begin{array}{l}\text { Al-Hadithi et al. (2009), } \\
\text { [27] }\end{array}$ & $0.39-0.54$ & 28 & $29-35$ & - & Compressive Strength \\
\hline $\begin{array}{l}\text { Harish et al. (2006), } \\
\text { [28] }\end{array}$ & 0.33 & $7-14$ & $38-57$ & - & Compressive Strength \\
\hline $\begin{array}{l}\text { Tolmachov et al. } \\
\text { (2017), [29] }\end{array}$ & 0.5 & $7-28$ & $39-51$ & - & Compressive Strength \\
\hline $\begin{array}{l}\text { Ahmed et al. (2016), } \\
\text { [30] }\end{array}$ & 0.52 & $7-56$ & $24-38$ & - & Compressive Strength \\
\hline $\begin{array}{l}\text { Desai et al. (2018), } \\
\text { [31] }\end{array}$ & - & $7-28$ & $15-25$ & $2-4$ & $\begin{array}{l}\text { Compressive and } \\
\text { Tensile Strengths }\end{array}$ \\
\hline Piraimathi (2017), [33] & - & $7-28$ & $33-50$ & - & Compressive Strength \\
\hline $\begin{array}{l}\text { Borole et al. (2016), } \\
\text { [35] }\end{array}$ & 0.45 & $7-28$ & $27-57$ & $2-4$ & $\begin{array}{l}\text { Compressive and } \\
\text { Tensile Strengths }\end{array}$ \\
\hline Remarks & $\begin{array}{l}\text { Varied } \\
\text { between } \\
0.28 \text { and } \\
0.79\end{array}$ & $\begin{array}{l}\text { Varied from } 7 \\
\text { up to } 90\end{array}$ & $\begin{array}{l}\text { Varied between } \\
10 \mathrm{MPa} \text { and } 62 \\
\mathrm{MPa}\end{array}$ & $\begin{array}{l}\text { Varied } \\
\text { between } 2 \\
\text { MPa and } 6 \\
\text { MPa }\end{array}$ & $\begin{array}{l}\text { Mainly compressive } \\
\text { strength tests were } \\
\text { used }\end{array}$ \\
\hline
\end{tabular}

\begin{tabular}{|c|c|c|c|c|c|c|}
\hline Reference & $\begin{array}{l}\text { Steel slag } \\
\text { content (\%) }\end{array}$ & w/c (\%) & $\begin{array}{l}\text { Curing time, } \\
\text { t (Day) }\end{array}$ & $\begin{array}{l}\text { Compressive } \\
\text { strength, } \sigma_{c} \\
(\mathrm{MPa})\end{array}$ & $\begin{array}{l}\text { Tensile } \\
\text { strength } \\
\sigma_{\mathrm{t}}(\mathrm{MPa}) \\
\end{array}$ & Types of test \\
\hline $\begin{array}{l}\text { Gupta et al. } \\
\text { (2017), [2] }\end{array}$ & $10-40$ & - & $7-28$ & $25-45$ & 4 & $\begin{array}{l}\text { Compressive and } \\
\text { Tensile Strengths }\end{array}$ \\
\hline $\begin{array}{l}\text { Anil et al } \\
\text { (2017), [7] }\end{array}$ & $11-44$ & - & $7-28$ & $26-43$ & $3-6$ & $\begin{array}{l}\text { Compressive and } \\
\text { Tensile Strengths }\end{array}$ \\
\hline $\begin{array}{l}\text { Palanisamy et } \\
\text { al. (2015), [8] }\end{array}$ & $10-36$ & 0.32 & $7-28$ & $42-70$ & $5-7$ & $\begin{array}{l}\text { Compressive and } \\
\text { Tensile Strengths }\end{array}$ \\
\hline $\begin{array}{l}\text { Shirale et al. } \\
(2009),[12]\end{array}$ & $5-15$ & 0.55 & $7-28$ & $30-59$ & $2-3$ & $\begin{array}{l}\text { Compressive and } \\
\text { Tensile Strengths }\end{array}$ \\
\hline $\begin{array}{l}\text { Ulubeyli et al. } \\
\text { (2015), [13] }\end{array}$ & $15-45$ & 0.5 & $7-28$ & $31-58$ & - & Compressive Strength \\
\hline $\begin{array}{l}\text { Olonade et al. } \\
\text { (2015), [14] }\end{array}$ & $25-100$ & $0.5-0.57$ & $7-28$ & $10-24$ & - & Compressive Strength \\
\hline $\begin{array}{l}\text { Devi et al. } \\
\text { (2014), [15] }\end{array}$ & $10-30$ & 0.55 & 28 & $23-28$ & - & Compressive Strength \\
\hline $\begin{array}{l}\text { Abrol et al. } \\
(2016),[18]\end{array}$ & $10-20$ & 0.5 & $7-28$ & $18-33$ & $2-3$ & $\begin{array}{l}\text { Compressive and } \\
\text { Tensile Strengths }\end{array}$ \\
\hline $\begin{array}{l}\text { Cabrera- } \\
\text { Madrid et al. } \\
(2016),[19]\end{array}$ & $15-30$ & $0.42-0.6$ & $28-90$ & $32-52$ & - & Compressive Strength \\
\hline $\begin{array}{l}\text { Desai et al. } \\
\text { (2018), [31] }\end{array}$ & $10-30$ & - & $7-28$ & $21-34$ & $3-4$ & $\begin{array}{l}\text { Compressive and } \\
\text { Tensile Strengths }\end{array}$ \\
\hline $\begin{array}{l}\text { Piraimathi } \\
\text { (2017), [33] }\end{array}$ & $10-40$ & - & $7-28$ & $31-59$ & - & Compressive Strength \\
\hline $\begin{array}{l}\text { Sezer et al. } \\
\text { (2015), [34] }\end{array}$ & 2.5 & $0.4-0.7$ & $7-90$ & $20-51$ & $2-4$ & $\begin{array}{l}\text { Compressive and } \\
\text { Tensile Strengths }\end{array}$ \\
\hline $\begin{array}{l}\text { Borole et al. } \\
\text { (2016), [35] }\end{array}$ & $25-50$ & 0.45 & $7-28$ & $16-60$ & 3 & $\begin{array}{l}\text { Compressive and } \\
\text { Tensile Strengths }\end{array}$ \\
\hline Remarks & $\begin{array}{l}\text { Varied } \\
\text { between } 2.5 \\
\text { and } 100\end{array}$ & $\begin{array}{l}\text { Varied } \\
\text { between } \\
0.32 \text { and } \\
0.7\end{array}$ & $\begin{array}{l}\text { Varied from } \\
7 \text { up to } 90\end{array}$ & $\begin{array}{l}\text { Varied between } 10 \\
\mathrm{MPa} \text { and } 70 \mathrm{MPa}\end{array}$ & $\begin{array}{l}\text { Varied } \\
\text { between } 2 \\
\mathrm{MPa} \text { and } 7 \\
\mathrm{MPa}\end{array}$ & $\begin{array}{l}\text { Mainly compressive } \\
\text { strength tests were used }\end{array}$ \\
\hline
\end{tabular}

gi14142@auis.edu.krd, la14158@auis.edu.krd, ss14524@auis.edu.krd, Ahmed.salih@auis.edu.krd $4 \quad{ }^{1}$ Corresponding author: College of Engineering, University of the American University of Iraq Sulaimani (AUIS) 


\section{RESULTS AND STATISTICAL VARIATIONS}

\subsection{Histogram analysis}

\subsubsection{Compressive strength $\left(\sigma_{c}\right)$}

The compressive strength histogram which shows 166 data sets of modified concrete with steel slag content up to curing of 90 days is studied and analyzed to show the frequency or most repeatable compressive strength values. According to Fig.1 (a), It is noticed 54\% of the obtained data sets are between $23 \mathrm{MPa}$ and 43 $\mathrm{MPa}$ of compressive strength. $30 \%$ of the data sets are $43 \mathrm{MPa}$ and above, and $17 \%$ of collected data sets are below $23 \mathrm{MPa}$.

\subsubsection{Tensile strength $\left(\sigma_{t}\right)$}

The histogram of tensile strength shows 90 numbers collected data sets of modified concrete with steel slag content in percentage up to curing of 90 days. As presented in Fig.1 (b), it is analyzed that $71 \%$ of the collected data sets are between 1.8 $\mathrm{MPa}$ and 4.3 MPa. However, 26\% of these data sets are more than $4.3 \mathrm{MPa}$.
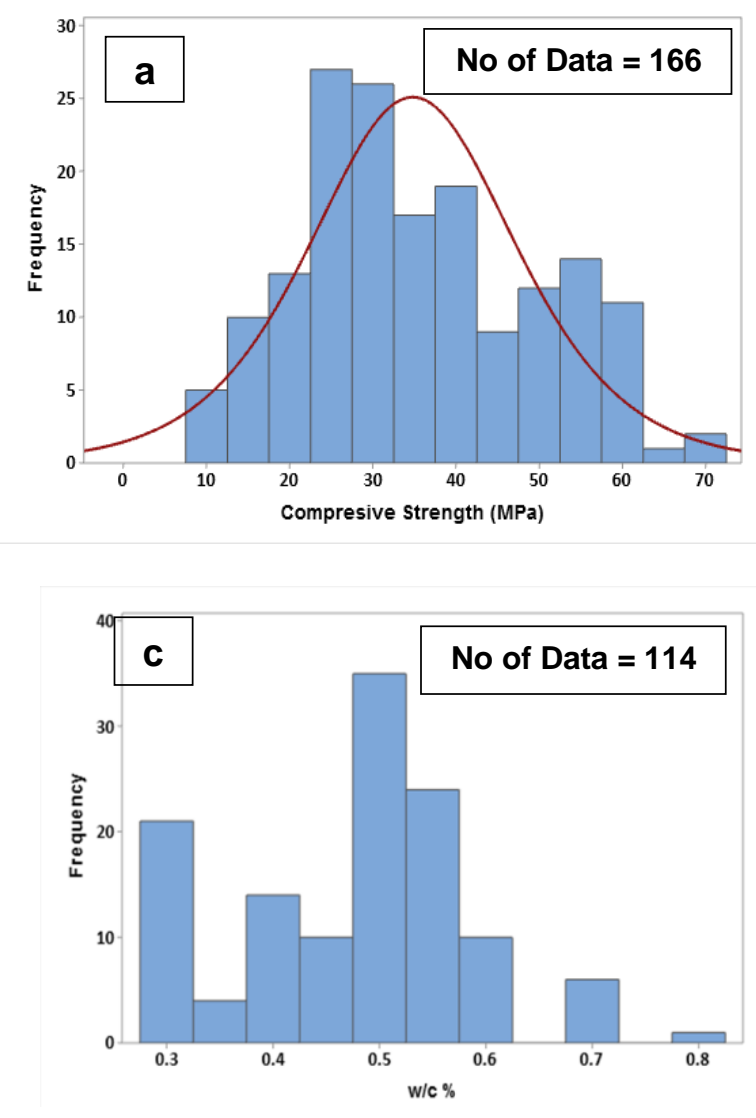

\subsubsection{Water to cement ratio (w/c \%)}

The water to cement ratio that has been used in such a modified concrete varies corresponding to different mix ratios. Based on Fig.1 (c) which is w/c histogram showing 125 obtained data sets until 90 days of age, $63 \%$ out of 125 collected data sets are ranging between 0.45 and 0.60 of $\mathrm{w} / \mathrm{c}$, and $8 \%$ of these data sets are more than 0.60 of w/c. However, $30 \%$ of the data sets are less than 0.45 of $w / c$.

\subsubsection{Steel slag content, (s \%)}

Steel slag content percentage used to modify concrete also varies based on different mix ratios. Fig. 1 (d) shows the histogram of 104 steel slag content percentages collected data sets from numbers of literature. It is obvious that $66 \%$ of these collected data sets are ranging between $10 \%$ and $30 \%$ of used slag content, and $26 \%$ of these data sets are more than $30 \%$ of slag content. However, $9 \%$ of the data sets are less than $10 \%$ of slag content.
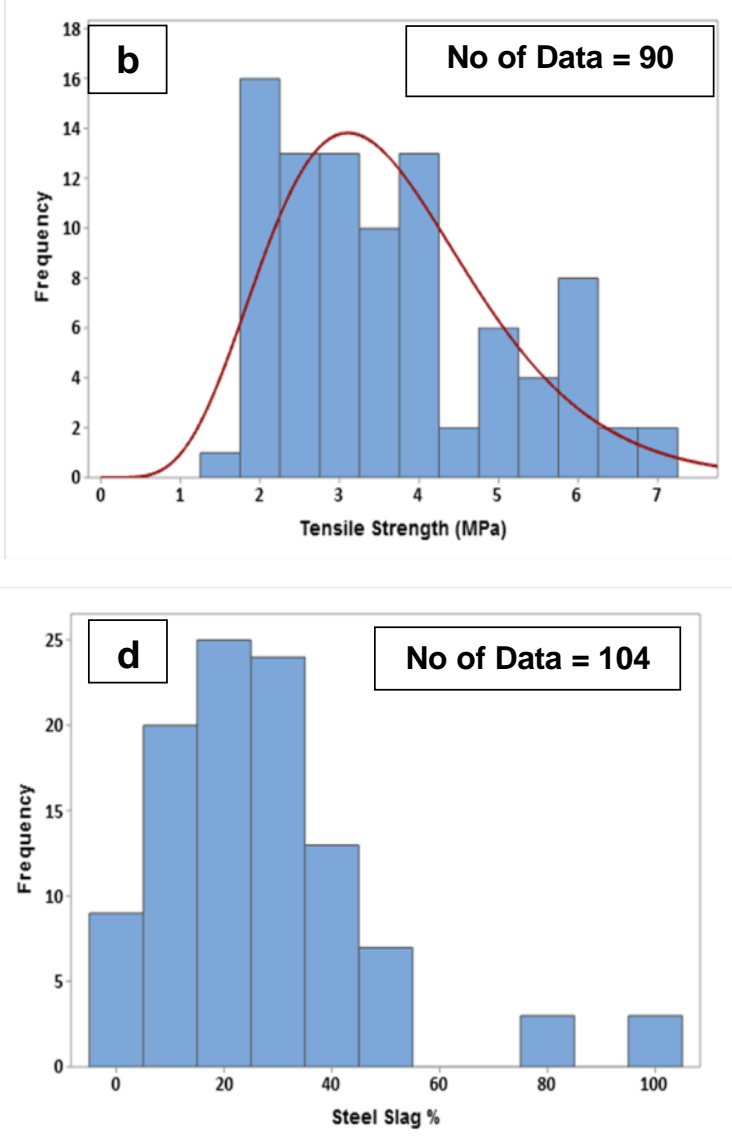

gi14142@auis.edu.krd, la14158@auis.edu.krd, ss14524@auis.edu.krd, Ahmed.salih@auis.edu.krd ${ }^{1}$ Corresponding author: College of Engineering, University of the American University of Iraq Sulaimani 
Fig. (1): Showing the histogram of mechanical properties of modified concrete, compressive strength (a), tensile strength (b) w/c (c), and \% steel slag content (d).

\subsection{Concrete mechanical property analysis \\ 3.2.1 Compressive strength $\left(\sigma_{c}\right)$}

I. Conventional concrete

Based on 65 numbers of compressive strength data sets collected from different research studies, compression-resistant range was among $10 \mathrm{MPa}$ and $60 \mathrm{MPa}$ with a mean value and standard deviation of 37 and 15.04 both respectively, and $40.6 \%$ of the corresponding COV as all shown in Table 3.

II. Modified concrete with a steel slag content

According to Table 2, collected compressive strength data of modified concrete are 101 data sets from various literature which are conducted on such type of concrete. Based on Table 3, compressive strength values of modified concrete range among $10 \mathrm{MPa}$ and $70 \mathrm{MPa}$. The mean value, standard deviation, and COV of compressive strength of concrete with slag content percentage are $33,12.3$, and $37.27 \%$ all respectively.

\subsubsection{Tensile strength $\left(\sigma_{t}\right)$}

\section{Conventional concrete}

The number of collected data sets of the tensile strength of conventional concrete is 29 referring to Table 1. Based on that amount of collected data, tensile strength varies between 2 $\mathrm{MPa}$ and $6 \mathrm{MPa}$. However, the mean value, standard deviation, and COV are 4, 1.53, and $38.25 \%$ all respectively as shown in Table 3 .

II. Modified concrete with a steel slag content

61 Numbers of tensile strength data of modified concrete with slag content in percentage are collected as shown in Table 2. Collected tensile strengths vary between 2-7 $\mathrm{MPa}$ with the mean value of 3 . The standard deviation and COV in percentages are 1.09 and $36.33 \%$ both respectively referring to Table 3 .

Table (3): Statistical analysis for the properties of conventional concrete and concrete modified with a steel slag content

\begin{tabular}{|c|c|c|c|c|}
\hline & Statistical parameters & $\mathbf{w} / \mathbf{c}$ & $\begin{array}{l}\text { Compressive Strength, } \sigma_{\mathrm{c}} \\
\text { (MPa) (up to } 90 \text { days of } \\
\text { curing) }\end{array}$ & $\begin{array}{l}\text { Tensile strength, } \sigma_{\mathrm{t}} \\
\text { (MPa)(up to } 90 \text { days } \\
\text { of curing) }\end{array}$ \\
\hline \multirow{5}{*}{ 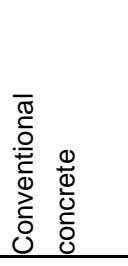 } & No. of Data & 55 & 65 & 29 \\
\hline & Range & $0.28-0.79$ & $10-62$ & $2-6$ \\
\hline & Mean $(\mu)$ & 0.48 & 37 & 4 \\
\hline & Std. Deviation $(\sigma)$ & 0.102 & 15.04 & 1.53 \\
\hline & $\operatorname{cov}(\%)$ & 21.25 & 40.6 & 38.25 \\
\hline \multirow{5}{*}{ 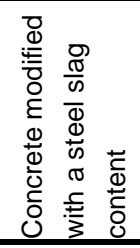 } & No. of Data & 70 & 101 & 61 \\
\hline & Range & $0.32-0.7$ & $10-70$ & $2-7$ \\
\hline & Mean $(\mu)$ & 0.48 & 33 & 3 \\
\hline & Std. Deviation $(\sigma)$ & 0.112 & 12.30 & 1.09 \\
\hline & $\operatorname{cov}(\%)$ & 23.33 & 37.27 & 36.33 \\
\hline
\end{tabular}

\section{MECHANICAL PROPERTY AND W/C, CURING TIME, AND STEEL SLAG DISCUSSIONS}

\subsection{Compressive strength $\left(\sigma_{\mathrm{c}}\right)$}

\subsubsection{The relationship between compressive} strength $\left(\sigma_{c}\right)$ and $w / c$

According to Fig.2 (a), compressive strength and w/c had an inversely proportional correlation. Even though points are scattering, it is obvious that as w/c ratio increases, the compressive strength gradually decreases to less than 20 $\mathrm{MPa}$, and is high between 0.30 and 0.50 of w/c. The main factor of such a relationship is that high w/c produces more voids and porosity which means increasing air spaces and a dilute paste has resulted. Thus, the concrete becomes weak in terms of strength, and is more subjected to shrinkage and crack development (Tauqir, 2018).

\subsubsection{The relationship between compressive} strength $\left(\sigma_{c}\right)$ and curing time

Compressive strength and curing time correlation which is recorded in $7,14,28,90$ days is not conventional. Meanwhile, based on Fig.2 (b), it is noticed that compressive strength is mostly measured in 7 and 28 days of curing, 
and it records about $70 \mathrm{MPa}$ in 28 days of curing. Concrete strength builds up with its age, and curing time plays a significant role in this subject by which it keeps the concrete moisture at its early age to go through a complete chemical reaction and hydration process after it is being placed, so that desired concrete strength can be developed (Kulkarni AVP, 2011).

\subsubsection{Compressive strength $\left(\sigma_{c}\right)$ and steel slag} content correlation

Referring to Fig.2 (c), compressive strength is directly proportional to steel slag content, which makes the concrete to be modified, up to $36 \%$ of replacement by steel slag content. The recorded highest compressive strength is $70 \mathrm{MPa}$ with $36 \%$ of utilized steel slag content. However, it is noticed that replacing by more than $36 \%$ leads to significantly decrease the compressive strength of modified concrete. The recorded compressive strength is $14 \mathrm{MPa}$ with $75 \%$ of used steel slag content. Hence, it is concluded that the more percentage of replacing fine aggregate by steel slag content does not mean the more strength of concrete results. The main reason is due to internal friction and the chemical reaction that the concrete experienced in such a mixture. According to collected data sets and Qasrawi, up to $36 \%$ of replacement, concrete can make more internal friction and strong boding among both slag content and remained a portion of fine aggregate due to its angularity shapes, and more than $36 \%$ replacement such two terms decreases due to sliding resulted with such ingredient amount that goes beyond equilibrium ratio. (Qasrawi et al, 2009).
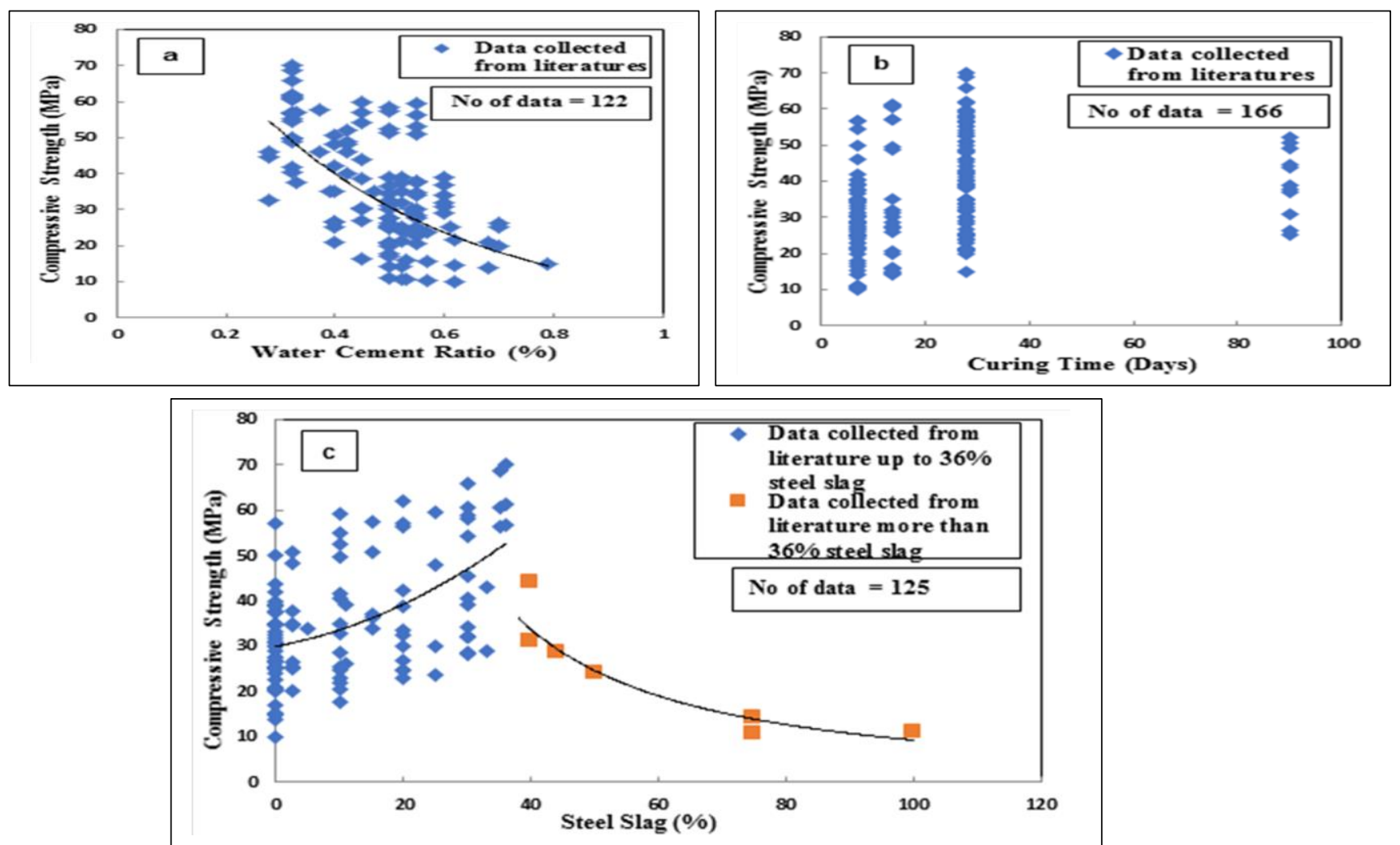

Fig. (2): Showing the relation of compressive strength with w/c, curing time, and steel slag in a modified concrete.

\subsection{Tensile strength $\left(\sigma_{t}\right)$}

4.2.1 Tensile strength $\left(\sigma_{t}\right)$ and $w / c$ correlation

As compression and w/c relation, tensile strength is also inversely proportional to the water-cement ratio. According to Fig.3 (a), when $\mathrm{w} / \mathrm{c}$ increases, the tensile strength of concrete gradually decreases up to less than $2 \mathrm{MPa}$. It is also observed that tensile strength scores its highest value between 0.20 and 0.40 of water to cement ratio and is $7 \mathrm{MPa}$. According to Tauqir, the factor discussed in section 4.1.1 is also applicable for such a tensile strength and w/c correlation.

\subsubsection{The relationship between tensile strength $\left(\sigma_{t}\right)$ and curing time}

As there is no clear relation between tensile strength and curing time, some points can be discussed. Tensile strength is also measured and recorded in 7, 14, 28, 90 days of curing. Like compressive strength, tensile strength is mostly 
tested in 7 and 28 days, and the highest tensile strength value is $7 \mathrm{MPa}$ in 28 days as shown in Fig.3 (b). Referring to Kulkarni study, the curing function and effectiveness discussed in section 4.1.2 can well describe tensile strength and curing time relationships as well.

\subsubsection{The relationship between tensile strength} $\left(\sigma_{t}\right)$ and steel slag content

According to Fig.3 (c), tensile strength is directly proportional to steel slag content up to $36 \%$ just like compressive strength. The highest tensile strength value is $7 \mathrm{MPa}$ in replacing sand by steel slag content with $36 \%$. On the other hand, the tensile strength tends to decrease as the replacement goes beyond 36\%. The tensile strength becomes $3 \mathrm{MPa}$ with $44 \%$ of used steel slag content. Hence, it is important to use the most workable amount of steel slag content to improve the strength of concrete. Referring to Qasrawi (2009), inclination and declination of tensile strength value due to various steel slag replacement is because of some reasons that are mentioned in section 4.1.3.
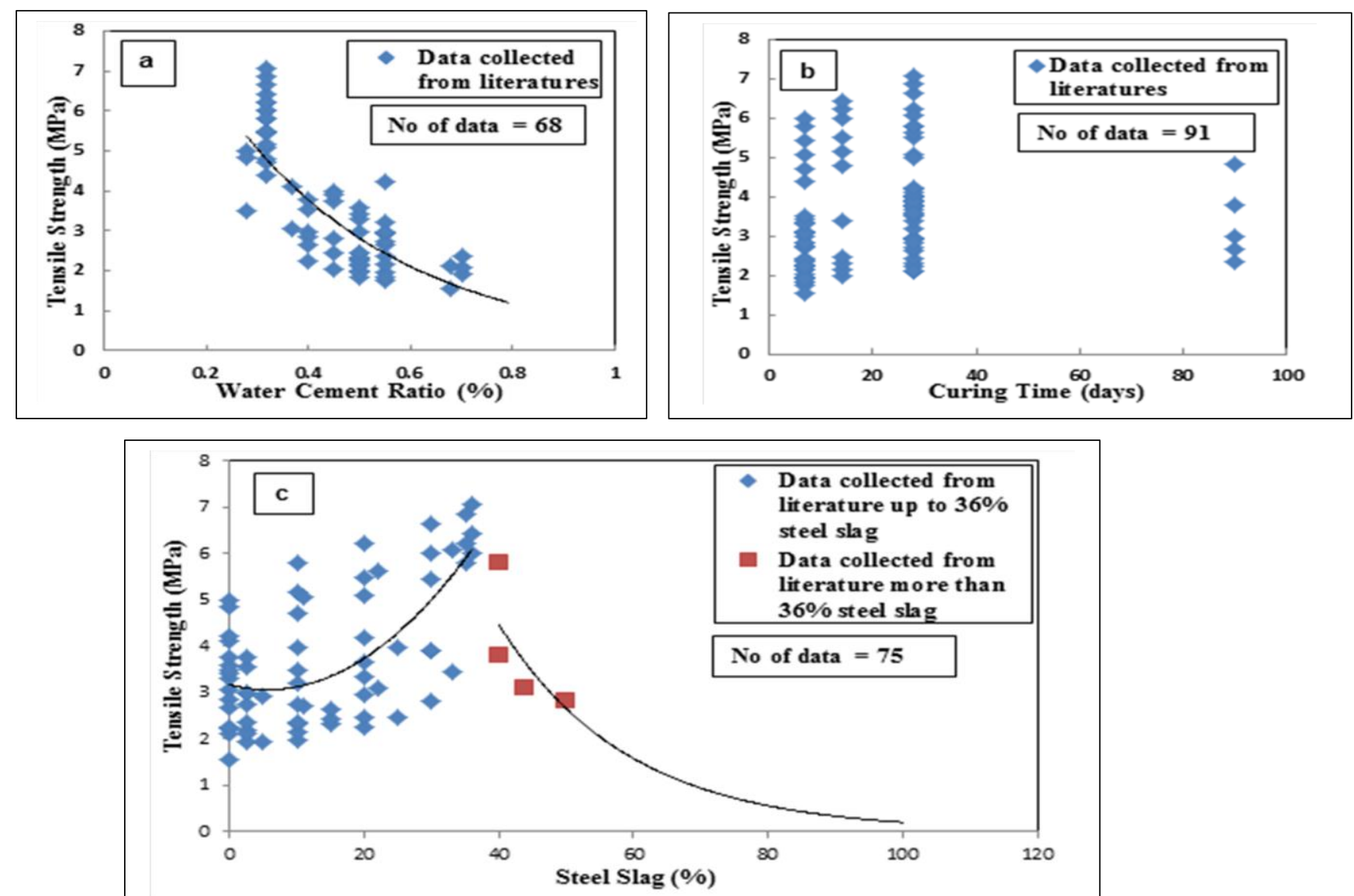

Fig. (3): Showing the relation of tensile strength with w/c, curing time, and steel slag in a modified concrete.

\subsection{Compressive strength $\left(\sigma_{c}\right)$ and tensile strength $\left(\sigma_{t}\right)$ relationship}

An obvious and significant correlation of both compressive and tensile strength is conducted which shows a linear relationship. According to Fig.4, tensile strength is directly proportional to compressive strength this is because both strengths increase and decrease simultaneously. Compressive strength starts from less than $20 \mathrm{MPa}$ to more than $60 \mathrm{MPa}$. With this increase of compressive strength, tensile strength also starts to increase from less than $2 \mathrm{MPa}$ to more than $6 \mathrm{MPa}$ since they have a positive linear correlation. 


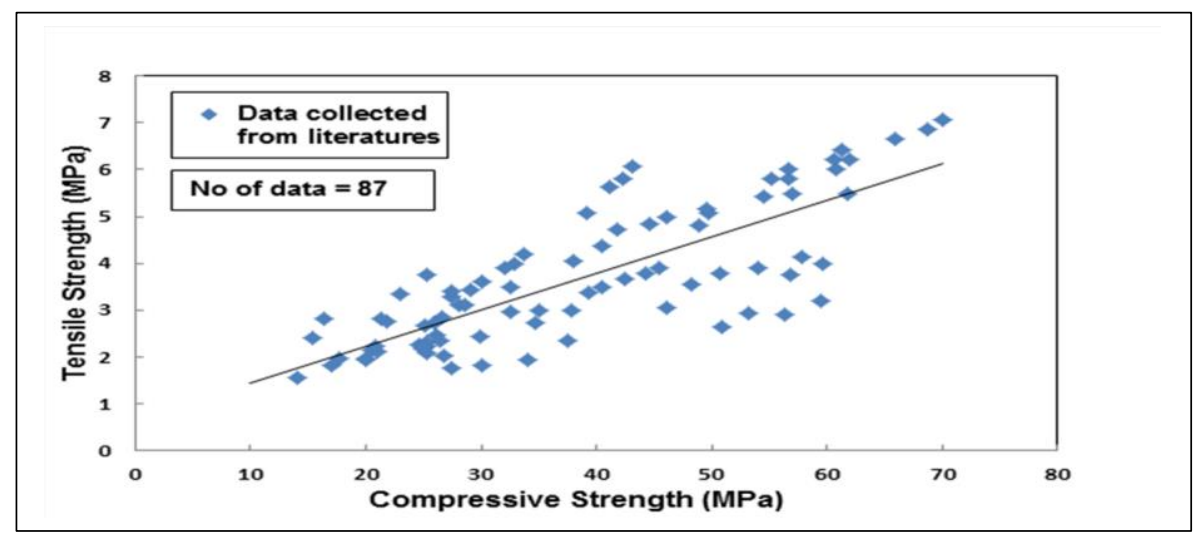

Fig. (4): The correlation of compressive strength with tensile strength.

\section{MODELED EQUATIONS OF PREDICTED MECHANICAL PROPERTIES}

5.1 The correlation of predicted compressive strength $\left(\sigma_{\mathrm{c}}\right)$ with experimented compressive strength $\left(\sigma_{c}\right)$ based on w/c, curing time, and steel slag content.

\subsubsection{Conventional concrete $(w / c$ and curing time)}

Compressive strength of conventional concrete, based on water to cement ratio and the time concrete is cured, varies according to its ingredient ratios and conditions as shown in 65 numbers of data collected from different literatures and listed in Table 1. Since compressive strength and w/c only cannot tell the exact behavior of conventional concrete, non-linear relationship model is used to show the predicted compressive strength behavior of concrete according to both w/c and curing time. Hence, w/c and curing time are the independent variables of compressive strength which would be the dependent variable by the following equation:

$$
\begin{gathered}
\sigma \mathrm{c}=5.75\left(\frac{\mathrm{w}}{\mathrm{c}}\right)^{-1.41} *(\mathrm{t})^{0.21}, \mathrm{R}^{2}=0.81, \text { No of } \\
\text { data }=45, \mathrm{RMSE}=5.15 \mathrm{MPa} \quad 4 \text { (a) }
\end{gathered}
$$

According to Fig.5 (a), a proper correlation is obtained for predicted and experimented compressive strength based on 45 numbers of data with an acceptable $\mathrm{R}^{2}$ of 0.81 . As shown in Table 4, the model parameters that lead to such a correlation are a, b, and c. According to their corresponding values, it can be stated that w/c has a higher impact on compressive strength than curing time. As long as w/c decreases, the predicted and experimented compressive strengths of conventional concrete increase.

\subsubsection{Modified concrete (w/c, curing time, and up to $36 \%$ steel slag content)}

Since a logical correlation of both compressive strength and only slag content percentage cannot be drawn, and it is also required to know at what moisture content and curing time certain compressive strengths are obtained, the compressive strength of modified concrete is correlated to all three in-dependent variables, such as w/c, curing time, and up to $36 \%$ of steel slag content. Hence, a more logical and reasonable correlation can be obtained by a non-linear relationship, equation 3. Based on 87 numbers of data out of listed compressive strengths of modified concrete by steel slag content up to $36 \%$ with up to 90 days of age and water to cement ratio in Table $1 \& 2$, a proper relationship is obtained between both predicted and experimented compressive strengths referring to Fig.5 (b). The model parameters achieved by using the least square method for such a relationship are shown in Table 4 .

$$
\begin{gathered}
\sigma \mathrm{c}=5.75\left(\frac{\mathrm{w}}{\mathrm{c}}\right)^{-1.41} *(\mathrm{t})^{0.21}+3.02\left(\frac{\mathrm{W}}{\mathrm{c}}\right)^{-1.05} \\
*(\mathrm{t})^{0.01} *(\mathrm{~s})^{0.13}
\end{gathered}
$$

$\mathrm{R}^{2}=0.80$, No. of data $=87$, RMSE $=6.32 \mathrm{MPa} \quad 4(\mathrm{~b})$

It is obvious that $b$ and e parameters of $w / c$ are both negative which shows that w/c is a more effective independent variable to the compressive strength of such a concrete compared to the other independent variables. However, the lower is w/c; the higher is the compressive strength. Following this, $\mathrm{g}$ parameter of steel slag content up to $36 \%$ is bigger than $\mathrm{f}$ parameter of curing time, in which it means that slag content is more effective term comparing to curing time till 90 days of curing. Nevertheless, parameter $\mathrm{d}$ which is multiplied by

gi14142@auis.edu.krd, la14158@auis.edu.krd, ss14524@auis.edu.krd, Ahmed.salih@auis.edu.krd ${ }^{1}$ Corresponding author: College of Engineering, University of the American University of Iraq Sulaimani (AUIS) 
w/c, curing time, and slag content is less than parameter a which is multiplied by w/c and concrete age by 2.75 . Left terms of the plus sign of the above equation equal to the compressive strength of conventional concrete; and right terms of the plus sign of the same equation equal to additional gained compressive strength due to sand replacement by slag content up to $36 \%$. Since the $d$ parameter equals 3 with a positive sign, the compressive strength of modified concrete becomes greater than compressive strength of conventional concrete. Thus, it can be concluded that concrete modified by steel slag content up to $36 \%$ experiences further improvement in terms of compressive strength, and such a resulted concrete can be used for special structures that require a greater strength with no additional cost. According to Tables $1 \&$ 2 and Fig.5 ( $\mathrm{a} \& \mathrm{~b}$ ), it is clear that the compressive strength of concrete increases in modified concrete with steel slag content up to $36 \%$ compared to conventional concrete.
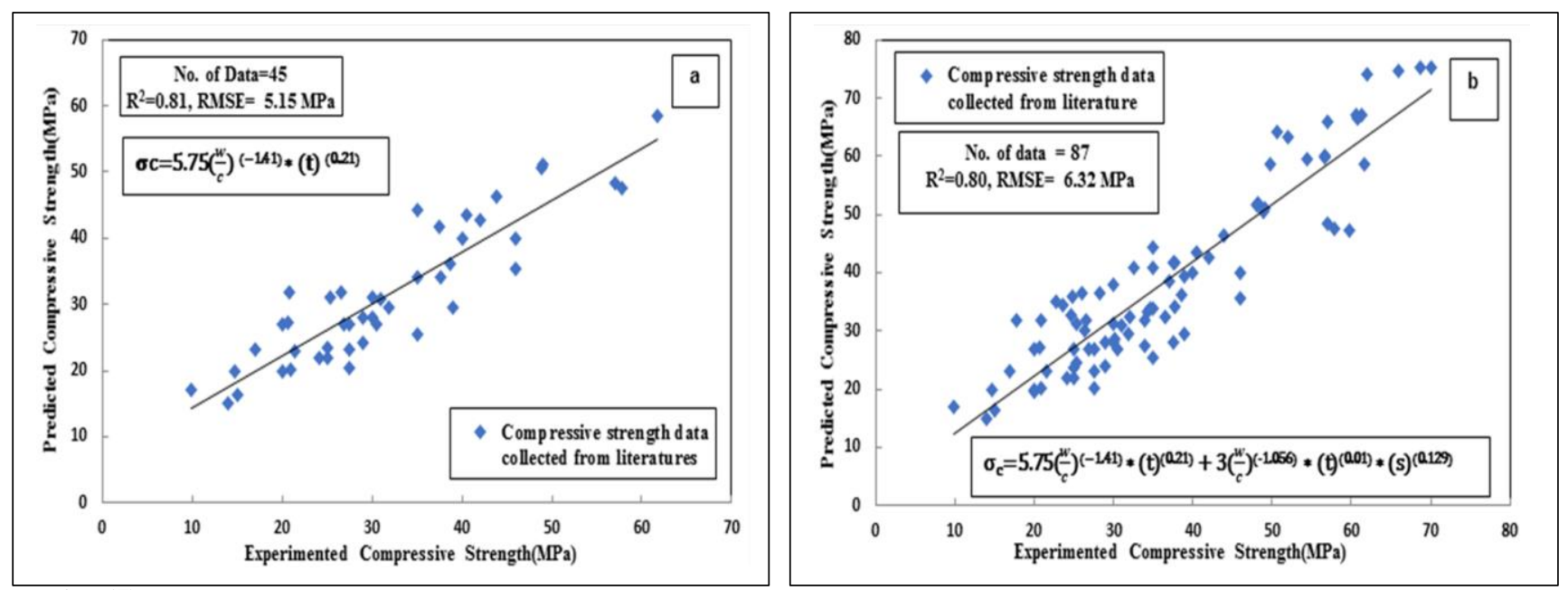

Fig. (5): Relationship between both predicted and experimented compressive strengths of conventional concrete (a) and modified concrete up to $36 \%$ of steel slag content (b).

5.2 The relationship of predicted and experimented tensile strength $\left(\sigma_{t}\right)$ based on $\mathrm{w} / \mathrm{c}$, curing time, and steel slag content.

\subsubsection{Conventional concrete (w/c and curing time)}

For tensile strength relationship, both w/c and time of curing are the independent variables to determine a proper correlation. This is because tensile strength and w/c only cannot tell the concrete behavior properly since the time that concrete is cured can also change the tensile strength of conventional concrete. It is needed to know at what w/c and curing time certain tensile strength has resulted. Using the non-linear relationship, equation 2, the relationship of predicted and experimented tensile strength of conventional concrete is made for 17 numbers of collected data out of listed numbers of tensile strength in Table 1 from various literature as shown in Fig.6 (a). Like compressive strength, the tensile strength of conventional concrete also increases as w/c decreases. The model parameter $\mathrm{b}$ of $\mathrm{w} / \mathrm{c}$ is small enough to give a higher tensile strength of concrete. Hence, w/c is an effective ingredient of concrete to the varying tensile strength of such concrete comparing to curing time.

$$
\begin{aligned}
& \sigma \mathrm{t}=0.87\left(\frac{\mathrm{w}}{\mathrm{c}}\right)^{-0.81} *(\mathrm{t})^{0.17}, \quad \mathrm{R}^{2}=0.80, \text { No of } \\
& \text { data }=17, \mathrm{RMSE}=0.46 \mathrm{MPa} \quad 5 \text { (a) } \\
& \text { 5.2.2 Modified concrete ( } w / c \text {, curing time, and } \\
& \text { up to } 36 \% \text { of steel slag content) }
\end{aligned}
$$

To determine reasonable values of the tensile strength of modified concrete with steel slag content up to $36 \%$, tensile strength is found based on independent variables of w/c, curing time, and slag content since it is required to know tensile strength of modified concrete with certain w/c, curing time, and slag content using equation 4. Great numbers of tensile strength values of modified concrete with slag content listed in Tables $1 \& 2$ are utilized to determine the predicted tensile strength of modified concrete referring to equation 5 (b). According to Fig.6 (b), a good relationship is drawn between both predicted and experimented tensile strength of modified concrete with slag content until-to $36 \%$ by a non-linear relationship. gi14142@auis.edu.krd, la14158@auis.edu.krd, ss14524@auis.edu.krd, Ahmed.salih@auis.edu.krd

$10{ }^{\mathrm{I}}$ Corresponding author: College of Engineering, University of the American University of Iraq Sulaimani (AUIS) 
$\sigma \mathrm{t}=0.87\left(\frac{\mathrm{w}}{\mathrm{c}}\right)^{-0.81} *(\mathrm{t})^{0.17}+0.36\left(\frac{\mathrm{w}}{\mathrm{c}}\right)^{-1.28} *$ $(\mathrm{t})^{0.07} *(\mathrm{~s})^{0.12}$

$\mathrm{R}^{2}=0.80$, No. of data $=49$, RMSE $=0.71 \mathrm{MPa} \quad 5(\mathrm{~b})$

Each model parameter has the power to change the predicted tensile strength of modified concrete to a certain extend. Like compressive strength, the tensile strength of modified concrete increases with less w/c that is why both $\mathrm{b}$ and $\mathrm{c}$ model parameters are in negative values, and it can be stated that $\mathrm{w} / \mathrm{c}$ is the most effective ingredient comparing to both curing time and steel slag content as shown in Table 4. Following this, a parameter multiplied by $\mathrm{w} / \mathrm{c}$ and time of curing is higher than $\mathrm{d}$ parameter multiplied by w/c, time of curing, and steel slag by 0.51 . The predicted tensile strength of conventional concrete equals the left terms of the plus sign of the above equation, and whatever value has resulted from the right terms of the plus sign that makes the concrete modified increases the tensile strength to be greater than the tensile strength of conventional concrete. Therefore, such a modification of concrete up to $36 \%$ of used slag content leads to obtain a higher tensile strength comparing to conventional concrete with no further increase in cost. Meanwhile, g parameter of steel slag content is bigger than $f$ parameter of curing time which shows that slag content additive is also a more effective parameter in changing tensile strength of modified concrete comparing to concrete age until $90 \quad$ days.
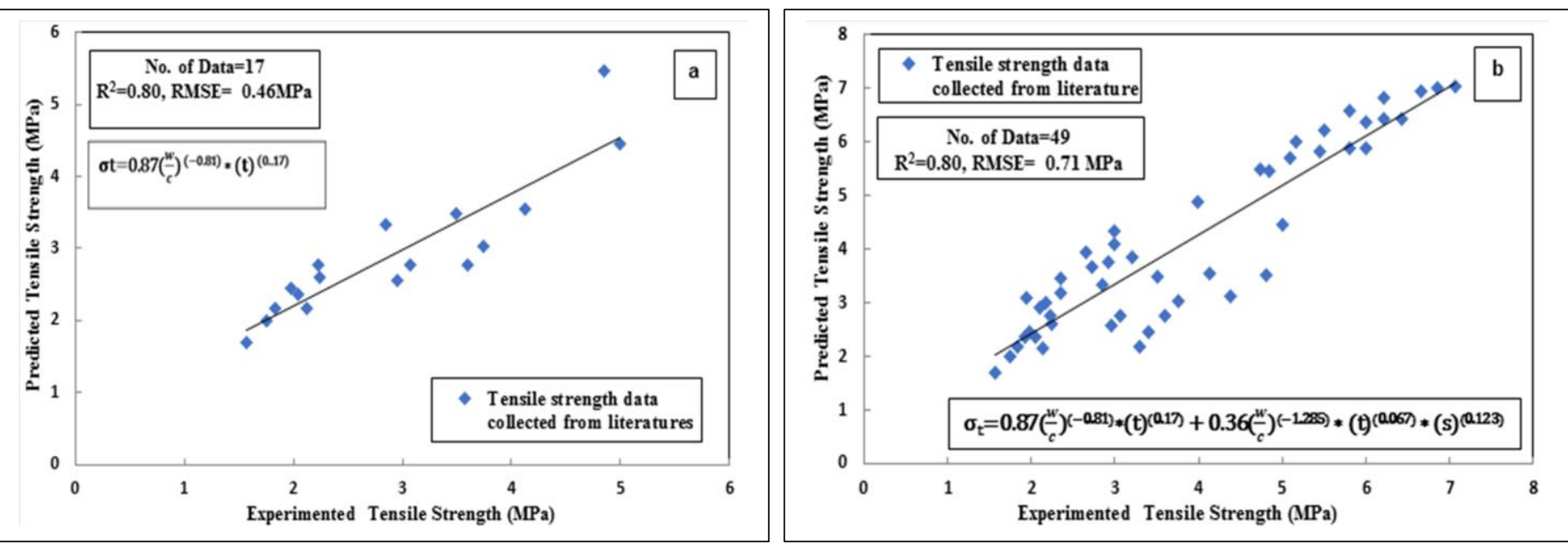

Fig. (6): Relationship between both predicted and experimented tensile strengths of conventional concrete (a) and modified concrete up to $36 \%$ of steel slag content (b).

5.3 The correlation of experimented and predicted tensile strength $\left(\sigma_{t}\right)$ based on compressive strength with modified concrete by steel slag content

Referring to the collected data from various literature experimented on modified concrete with steel slag content and conventional concrete as listed in Table 1 and Table 2, a significant and proper relationship is drawn between experimented compressive strength and the predicted value of tensile strength of modified concrete comparing to experimented tensile and compressive strength of such concrete using Vipulanandan correlation model, equation 1, as shown in Fig. 7.

$$
\begin{aligned}
& \sigma \mathrm{t}=\frac{\sigma \mathrm{c}}{(20.6)-(0.10)(\sigma \mathrm{c})}+(1.26), \mathrm{R}^{2}=0.81, \text { No of } \\
& \text { data }=76, \mathrm{RMSE}=0.62 \mathrm{MPa}
\end{aligned}
$$

Based on 76 numbers of collected data the model is obtained between predicted tensile strength and experimented compressive strength comparing to both experimented compressive and tensile strength of modified concrete. The model of tensile strength is quite close and acceptable compared to the experimental values. It can be stated that as the experimented tensile and compressive strength increases, predicted tensile strength also increases significantly which substantiates the accuracy of draw model with the above equation and $\mathrm{R}^{2}$ and RMSE of 0.81 and $0.62 \mathrm{MPa}$ respectively. According to Fig. 7, both experimented and predicted tensile strength starts from $2 \mathrm{MPa}$ up to more than 6MPa. Referring to Table 4, b model parameter is more effective to the predicted tensile strength of modified concrete comparing to a \& c model parameters. This is because $\mathrm{b}$ parameter lowers the compressive strength by the factor of 0.1 which is about $10 \%$ to obtain more accurate values of predicted tensile strength. Thus, it can be claimed that tensile strength is about $10 \%$ of the compressive strength of modified concrete. 


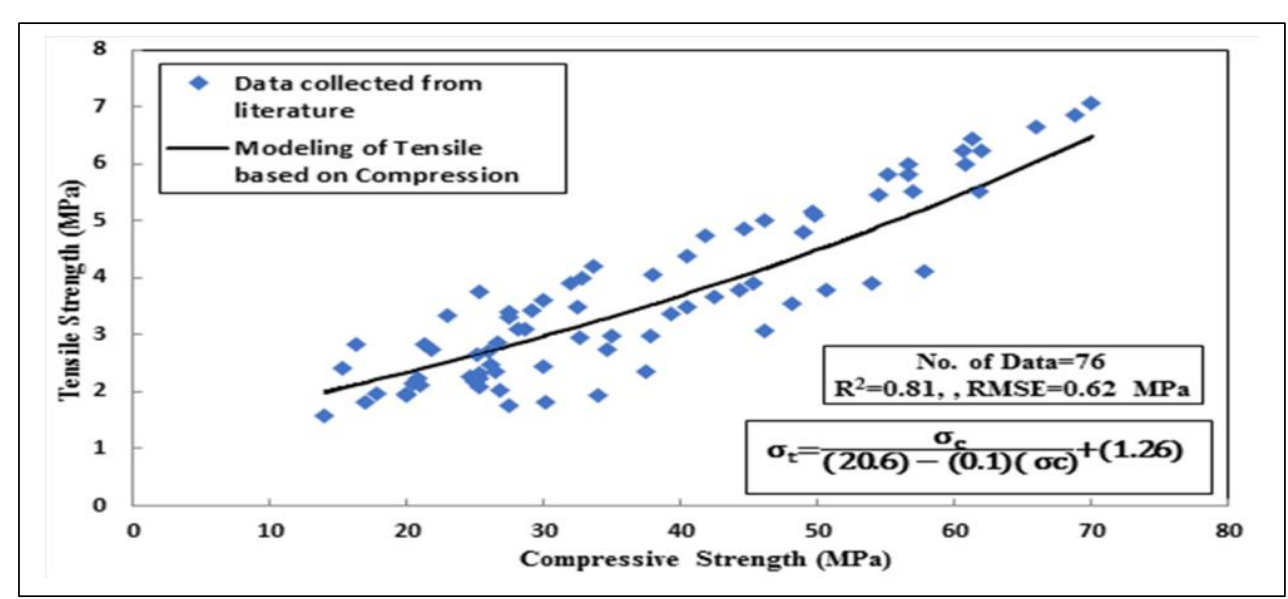

Fig. (7): The correlation of experimented compressive and tensile strength with predicted tensile strength based on compressive strength for modified concrete with steel slag

Table (4): The model parameters of both Vipulanandan and Non-Linear Relationship Model

\begin{tabular}{|c|c|c|c|c|c|c|c|c|c|c|c|c|}
\hline & $\begin{array}{l}\text { Depended } \\
\text { Variables (Y- } \\
\text { axis) } \\
\end{array}$ & $\begin{array}{l}\text { In-depended } \\
\text { Variables (X- } \\
\text { axis) }\end{array}$ & $\mathbf{a}$ & b & c & d & $E$ & $f$ & $\mathbf{g}$ & $\begin{array}{l}\text { RMSE } \\
\text { (MPa) } \\
\end{array}$ & R2 & $\begin{array}{l}\text { Figure. } \\
\text { No } \\
\end{array}$ \\
\hline \multirow[t]{2}{*}{ 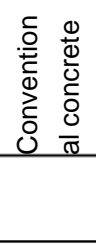 } & $\begin{array}{l}\text { Compressive } \\
\text { strength } \sigma c \\
(\mathrm{MPa})\end{array}$ & $\begin{array}{l}\text { w/c \& curing } \\
\text { time }\end{array}$ & 5.75 & -1.41 & 0.21 & - & - & - & - & 5.15 & 0.81 & 5 (a) \\
\hline & $\begin{array}{l}\text { Tensile strength } \\
\text { ot (MPa) }\end{array}$ & $\begin{array}{l}\text { w/c \& curing } \\
\text { time }\end{array}$ & 0.87 & -0.81 & 0.17 & - & - & - & - & 0.46 & 0.80 & 6 (a) \\
\hline \multirow[t]{3}{*}{ 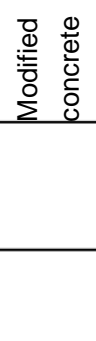 } & $\begin{array}{l}\text { Compressive } \\
\text { strength } \sigma c \\
(\mathrm{MPa})\end{array}$ & $\begin{array}{l}\text { w/c, curing } \\
\text { time, \& steel } \\
\text { slag up to } 36 \%\end{array}$ & 5.75 & -1.41 & 0.21 & 3.02 & -1.05 & 0.01 & 0.13 & 6.32 & 0.80 & 5 (b) \\
\hline & $\begin{array}{l}\text { Tensile strength } \\
\text { ot (MPa) }\end{array}$ & $\begin{array}{l}\text { w/c, curing } \\
\text { time, \& steel } \\
\text { slag up to } 36 \%\end{array}$ & 0.87 & -0.81 & 0.17 & 0.36 & -1.28 & 0.07 & 0.12 & 0.71 & 0.80 & 6 (b) \\
\hline & $\begin{array}{l}\text { Tensile strength } \\
\text { ot (MPa) }\end{array}$ & $\begin{array}{l}\text { Compressive } \\
\text { strength }\end{array}$ & 20.6 & -0.10 & 1.26 & - & - & - & - & 0.62 & 0.81 & 7 \\
\hline
\end{tabular}

\section{CONCLUSIONS}

The core of this research was to examine and determine the impact of water-cement ratio, concrete age, and steel slag on the compression and tension behavior of modified concrete. Referring to the previous literature, data and logical models has been collected and developed in this research, the following points are advanced conclusion:

1. The conducted analysis defined the steel slag content mean value which was $11.2 \%$ used in the modification of concrete. Slag content percentage varied between 2.5 and $100 \%$. However, compressive and tensile strength reached their maximum values in modified concrete by steel slag content up to $36 \%$. With more than $36 \%$ of utilized slag content, less strength of compressive and tensile was observed.

2. The average of w/c of the concrete without the use of slag content was 0.48 , also for modified concrete with slag content; the average of w/c was the same 0.48 . The range of water-cement ratio was between 0.32 and $0.7 \%$.

3. There was a Non-Linear correlation between compressive and tensile strength with watercement ratio, curing time, and slag content in modified concrete with steel slag content.

4. Relying on the Non-Linear model parameters, steel slag had less impact rather than w/c on the mechanical properties of modified concrete.

5. Steel slag content up to $36 \%$ was an important and effective additive with w/c and curing time gi14142@auis.edu.krd, la14158@auis.edu.krd, ss14524@auis.edu.krd, Ahmed.salih@auis.edu.krd

$12{ }^{\mathrm{I}}$ Corresponding author: College of Engineering, University of the American University of Iraq Sulaimani (AUIS) 
to improve the mechanical properties of modified concrete compared to conventional concrete.

6. Compressive strength of modified concrete with slag up to $36 \%$ is proportionally increased with the increase of tensile strength and reached their maximum strength of $70 \mathrm{Mpa}$ and $7 \mathrm{Mpa}$ respectively.

\section{REFERENCES}

Gupta, H., \& Sexena, A. K. (2017). Strength Properties of Steel Slag in Concrete. International Journal of Engineering Research \& Technology (IJERT), 6(11).

Burhan, L., Ghafor, K., \& Mohammed, A. (2019). Modeling the effect of silica fume on the compressive, tensile strengths and durability of NSC and HSC in various strength ranges. Journal of Building Pathology and Rehabilitation, 4(1), 19.

Uddin, M., Jameel, M., Sobuz, H. R., Hasan, N. M., Islam, M., \& Amanat, K. M. (2012). The effect of curing time on the compressive strength of composite cement concrete. In Applied Mechanics and Materials, 204, 41054109.

Tauqir, A. (2018). Determination of Water/Cementratio of Cement.

Akinwumi, I. I., \& Gbadamosi, Z. O. (2014). Effects of curing condition and curing period on the compressive strength development of plain concrete. International Journal of Civil and Environmental Research, 1(2), 83-99.

Nemati, K. M. (2015). Strength of Concrete. Concrete Technology, 1-18.

Janković, K., Nikolić, D., Bojović, D., Lončar, L., \& Romakov, Z. (2011). The estimation of the compressive strength of normal and recycled aggregate concrete. Facta universitatis-series: Architecture and Civil Engineering, 9(3), 419431.

Liu, J., \& Guo, R. (2018). Applications of Steel Slag Powder and Steel Slag Aggregate in UltraHigh Performance Concrete. Advances in Civil Engineering, 2018, 1-8.

Anil, M. K., \& Pankaj, P. K. (2017). Effect of Steel Slag as Partial Replacement of Fine Aggregate in M35 Grade of Concrete. Imperial Journal of Interdisciplinary Research (IJIR), 3(9), 2454-1362.

Palanisamy, S. P., Maheswaran, G., Annaamalai, M. G. L., \& Vennila, P. (2015). Steel slag to improve the high strength of concrete. Int $J$ Chem Tech Res, 7, 2499-2505.

Shirale, R. L., Kale, K. R., \& Dahake, A. G. (2019). Effect of Steel Slag and Bagasse Ash on Strength of Concrete. Journal of Experimental \& Applied Mechanics, 8, 1-10.

Ulubeyli, G. C., \& Artir, R. (2015). Sustainability for blast furnace slag: use of some construction wastes. Procedia-social and behavioral sciences, 195, 2191-2198.
Olonade, K. A., Kadiri, M. B., \& Aderemi, P. O. (2015). Performance of steel slag as fine aggregate in structural concrete. Nigerian Journal of Technology, 34, 452-458.

Devi, V. S., \& Gnanavel, B. K. (2014). Properties of concrete manufactured using steel slag. Procedia Engineering, 97, 95-104.

Ismaili, M., Bhutta, M. A. R., Noruzman, A. H. (213). Mechanical properties of polymer modified concrete with addition of vinyl acetate waste, The Seventh International Structural Engineering and Construction Conference.

Khazaal, A. S. (2014). Normal Strength Concrete Mix Design Technical Report. Engineering Consulting Bureau. Tikrit

Abrol, S., Sharma, P., Verma, N., \& Singh, I. (2016). EFFECT OF STEEL SLAG IN CONCRETE. International Journal of CivilEngineering, 3(2), 1694-2396.

Cabrera-Madrid, J. A., Escalante-García, J. I., \& Castro-Borges, P. (2016). Compression resistance of concretes with blast furnace slag. Re-visited state-of-the-art. Revista ALCONPAT, 6(1), 64-83.

Hilles, M. M., \& Ziara, M. M. (2019). Mechanical behavior of high strength concrete reinforced with glass fiber. Engineering Science and Technology, an International Journal, 22, 920-928.

Palson, P., \& Vidivelli, B. (2017). Mechanical properties of latex modified concrete with silica fume. International Journal of Civil Engineering and Technology, 8(9), 701-710.

Ammash, H. K., Hemzah, S. A., \& Jasim, R. (2017). Effect of Using Plastic Waste on Mechanical Properties of Concrete. Menoufia University, Faculty of Engineering. Ninth Conference of Sustainable Environmental Development.

Noori, K. M. G., \& Ibrahim, H. I. (2018). Mechanical Properties of Concrete Using Iron Waste as a Partial Replacement of Sand. In 4th International Engineering Conference on Developments in Civil \& Computer Engineering (pp. 204-215).

Al-Ahdal, B. M. S., Xiong, L. B., \& Tufail, R. F. (2018). Mechanical properties of concrete containing Fly Ash, Rice Husk Ash and Waste Glass Powder. Civil Engineering Journal, 4, 1019-1033.

Munaf, D. R., Besari, M. S., IqbaP, M. M., \& Kadir, I. (2001). The mechanical properties of fly ash concrete prepared and cured at high temperatures. ASEAN Journal on Science and Technology for Development, 18, 1-10.

Ion, I., Barroso Aguiar, J., Angelescu, N., \& Stanciu, D. (2013). Properties of polymer modified concrete in fresh and hardened state. In Advanced Materials Research, 687, 204-212.

Al-Hadithi, A. I., \& Al-Nu'man, B. S. (2009). Flexural Behaviour of Polymer Modified Reinforced Concrete Beams. Journal of

gi14142@auis.edu.krd, la14158@auis.edu.krd, ss14524@auis.edu.krd, Ahmed.salih@auis.edu.krd ${ }^{1}$ Corresponding author: College of Engineering, University of the American University of Iraq Sulaimani 
Engineering and Sustainable Development, 13, 89-110.

Harish, G. R., Zai, S. A., \& Chandramouli, S. V. (2016). Experimental Study on Compression and Flexure Test on SBR Latex Modified Polypropylene Fiber Concrete. International Journal of Engineering Research \& Technology (IJERT), 5, (4).

Tolmachov, S., Belichenko, O., \& Zakharov, D. (2017). Influence of additives on flexural strength of concrete. In MATEC Web of Conferences, 116, 1160-1019.

Ahmed, M., Mallick, J., \& Hasan, M. A. (2016). A study of factors affecting the flexural tensile strength of concrete. Journal of King Saud University-Engineering Sciences, 28, 147-156.

Desai, G., Lohakare, P., Bhavsar, A., Ugale, A., \& Bhavsar, N. (2018). Partial replacement of fine aggregate using steel slag. International Journal of Engineering Development and Research, 6(2), 2321-9939.

Piraimathi, S. (2017). A STUDY ON CONCRETE PROPERTIES USING STEEL SLAG AS PARTIAL REPLACEMENT OF COARSE AGGREGATE. Global Journal of Engineering Science and Research., 4, 201216.

Sezer, G. İ., \& Gülderen, M. (2015). Usage of steel slag in concrete as fine and/or coarse aggregate. Indian Journal of Engineering \& Materials Sciences, 22(3), 339-344.

Borole, S. T., Shinde, R. V., Mhaske, R. B., Pagare, S. S., Tribhuvan, K. S., Pawar, N. M., ... \& Sanehi, A. K. (2016). Replacement of fine aggregate by steel slag. International Journal of Innovative Research in Science and Engineering, 2(3), 628-635.

ACI Committee. (2011). Guide to Quality Control and Assurance of High-Strength Concrete. American Concrete Institute.

Kulkarni, S.B., Pereira,C. (2011). Significance of Curing of Concrete for Durability of Structures. NBM Construction Information Porta.

Qasrawi, H., Shalabi, F., \& Asi, I. (2009). Use of low $\mathrm{CaO}$ unprocessed steel slag in concrete as fine aggregate. Construction and Building Materials, 23(2), 1118-1125.

Vipulanandan, C., and A. Mohammed. (2020). Magnetic field strength and temperature effects on the behavior of oil well cement slurry modified with iron oxide nanoparticles and quantified with vipulanandan models. Journal of Testing and Evaluation 48, no. 6.

Mahmood, W., Mohammed, A. (2020). Hydraulic Conductivity, Grain Size Distribution (GSD) and Cement Injectability Limits Predicted of Sandy Soils Using Vipulanandan Models. Geotech Geol Eng 38, 2139-2158.

Burhan, L., Ghafor, K., \& Mohammed, A. (2020). Enhancing the Fresh and Hardened Properties of the Early Age Concrete Modified with Powder Polymers and Characterized Using Different Models. Advances in Civil Engineering Materials, 9(1), 227-249.

Mohammed, A, and Mahmood, W. (2018). Statistical variations and new correlation models to predict the mechanical behavior and ultimate shear strength of gypsum rock. Open Engineering 8,

gi14142@auis.edu.krd, la14158@auis.edu.krd, ss14524@auis.edu.krd, Ahmed.salih@auis.edu.krd

$14{ }^{1}$ Corresponding author: College of Engineering, University of the American University of Iraq Sulaimani (AUIS) 